\title{
Teaching reading using ReadTheory website as an online platform Fitrotunnisa Alhaniah ${ }^{1}$, Dian Shafwati ${ }^{2}$ \\ English Education Study Program, University of Lampung ${ }^{1,2}$ \\ ${ }^{1}$ Correspondence: fnalhaniah@gmail.com
}

\begin{abstract}
The objectives of this research were to know whether or not there is a significant improvement on reading achievement after teaching using ReadTheory and which reading aspect is improved the most. The design of this study was one group pretest-post test design. The study employed reading test for pretest and post test. The result of study found that the two tailed significance value (p) is 0.000. ReadTheory is significant to improve reading achievement and supporting details are the aspect improved the most. This is proven as the result of post test mean reached 62,59 from 53,40. The improvement was shown in all aspects of reading, especially aspect of supporting details. The gain percentage of supporting details was $13.6 \%$. Thus, the teachers can try to employ ReadTheory in order to enhance reading practice especially in aspects of supporting details.
\end{abstract}

Key Words: ReadTheory, improvement, reading test, reading aspect.

\section{INTRODUCTION}

Reading is one of the key language learning and teaching competencies. Chastain (1988) claimed that students of the second and international languages need to read vast amounts of authentic materials to be able to read for communication. Among the four English skills, reading is more emphasized to be taught in Indonesia as the item tests of the Ujian Tulis Berbasis Komputer (university entrance test) focus on the reading achievement (Lembaga Tes Masuk Perguruan Tinggi, 2020).

Some studies have been done in investigating reading achievement through online platform. One study aims to see the ReadTheory's impact on student grades, reading confidence and ability (Romeo, 2016). Another study aims to see the significant influence of online reading habit on reading achievement (Yuliani, 2017). Another study aims to see reading strategy towards student reading achievement (Khusniyah, 2019). Another study aims to see the EFL's factors influence of reading habit (Satriani, 2019).

The word "online platform" has been used to describe a number of online platforms, including markets, search engines, social media, innovative content sources, app stores, messaging platforms, payment systems, so-called "collaborative" or "gig" economies, and much more. An online platform is defined in this study as a digital service that facilitates interactions between two or more separate but interdependent sets of users (whether companies or individuals) who interact via the internet through the service (OECD, 2019).

Online learning is a teaching and learning process using internet and digital media to transfer the materials (OECD, 2019). The sources of online learning and e learning are from website, internet, CD-ROM, and DVD. The purpose of online and e-learning is not only to access information but also to achieve specific learning purpose (Ayu, 2020). Most learning tasks will be completed through the help of technology. This can be proved by looking at today's educational institutions where many schools have their own website to disseminate and share information with the students quickly. 
Indeed the learning environment affects new information growth. This includes the physical facilities, the psychological environment, the methods of learning and teaching (Haron, 2015).

It is not surprising that the more one reads, the better one becomes at reading. Readtheory.org as an online platform has numerous reading worksheets. ReadTheory.org is an interactive website designed to serve as a computer-based supplemental reading program for students in grades 1 through 12 at ESL. The website provides a wide variety of reading achievement exercises. ReadTheory's unique features are its fee-for-use model, its incorporation of game mechanics, and its responsive leveling algorithm, which allows students to be presented with best-fit material based on prior performance (Romeo, 2016).

\section{METHOD}

The aim of the study is to find out if there would be a significant difference in the achievement by students through the implementation of reading using ReadTheory. The aspects of reading that are best promoted through online platforms are also examined. The study one group pretest-post test design. The researcher used statistical computation Paired Sample T-Test SPSS 20 version for Windows to test whether there is significant difference or not. The study is designed as follows:

\section{T1 X T2}

(Setiyadi, 2006)

$\mathrm{T} 1$ is the pretest, $\mathrm{X}$ is the experiment of using ReadTheory. After the class get the treatment, they have the post test (T2). The data were analyzed by using two paired t-test. The researcher uses purposive sampling in order to represent the objectives of the research (Setiyadi, 2006). Students of 10th grade at SMAN 11 Bandar Lampung were chosen as the subject of the research.

\section{RESULT AND DISCUSSION}

\section{Result}

Table 1. Result of Paired Samples Test

Paired Samples Test

\begin{tabular}{|c|c|c|c|c|c|c|c|c|}
\hline & \multicolumn{5}{|c|}{ Paired Differences } & \multirow{3}{*}{\multicolumn{2}{|c|}{$\mathrm{df}$}} & \multirow{3}{*}{$\begin{array}{l}\text { Sig. } \\
\text { tailed })\end{array}$} \\
\hline & \multirow[t]{2}{*}{ Mean } & \multirow[t]{2}{*}{$\begin{array}{l}\text { Std. } \\
\text { Deviatio } \\
\mathrm{n}\end{array}$} & \multirow[t]{2}{*}{$\begin{array}{l}\text { Std. } \\
\text { Error } \\
\text { Mean }\end{array}$} & \multicolumn{2}{|c|}{$\begin{array}{l}\text { 95\% Confidence } \\
\text { Interval of the } \\
\text { Difference }\end{array}$} & & & \\
\hline & & & & Lower & Upper & & & \\
\hline $\begin{array}{ll}\text { Pai } & \text { PreTest } \\
\text { r } 1 & \text { PostTest }\end{array}$ & $\begin{array}{l}- \\
-9.181 \\
82\end{array}$ & 7.02808 & 1.49839 & $\begin{array}{l}- \\
12.297 \\
90\end{array}$ & - & -6.128 & 21 & .000 \\
\hline
\end{tabular}

Table 1 above shows the two tailed significance value (p) is 0.000 . It means that the improvement on students' reading achievement is significant. In other words, the hypothesis is accepted since 0.000 is 
less than $0.05(0.00<0.05)$. Therefore, it can be concluded that students' reading achievement significantly improved after the implementation of ReadTheory website. Students' mean score in the pre-test is 53.40, while the mean score of post test is 62.59 .

The research finding indicates that the implementation of ReadTheory had led to significant improvement of students' reading achievement. The students' mean score in the pre-test was 53,40 . In the post-test, students got 62,59 on their reading achievement. Then, it was found out that the significance level of students' improvement was 0,000 . The improvement was shown in some aspects of reading which were supporting details, reference and main idea. Among all the aspects, supporting details is the highest aspect improved.

ReadTheory fits with the criteria of what online platform should be. It has educational value of online learning platforms and the affordances of resources in creating innovative assessment practices (Fernando, 2018). All content on ReadTheory is in line with grade-specific Common Core State Standards on English Language Arts, reassuring that in-program progress reflects to offline success on state standardized tests (Common Core, 2010).

There are six principles behind teaching reading such as: reading is not a passive skill, students need to be engaged with what they are reading, student should be encouraged to respond to the content of a reading text, prediction is the ultimate factor and the teacher should match up the task with topics (Harmer, 2001). The researcher used the instrument as pre-test and post-test to see the aspect improvement. The aspect and its percentage as follow:

Table 2. Aspects Percentage of Pre-Test and Post Test

\begin{tabular}{|cc|}
\hline Aspects & Percentage \\
\hline Main Idea & $20 \%$ \\
\hline $\begin{array}{c}\text { Supporting } \\
\text { Details }\end{array}$ & $20 \%$ \\
\hline Reference & $20 \%$ \\
\hline Inference & $20 \%$ \\
\hline Vocabulary & $20 \%$ \\
\hline
\end{tabular}

There are five aspects to be tested such as main idea, supporting details, reference, inference and vocabulary. The improvement of each aspect in a bar chart as follow: 


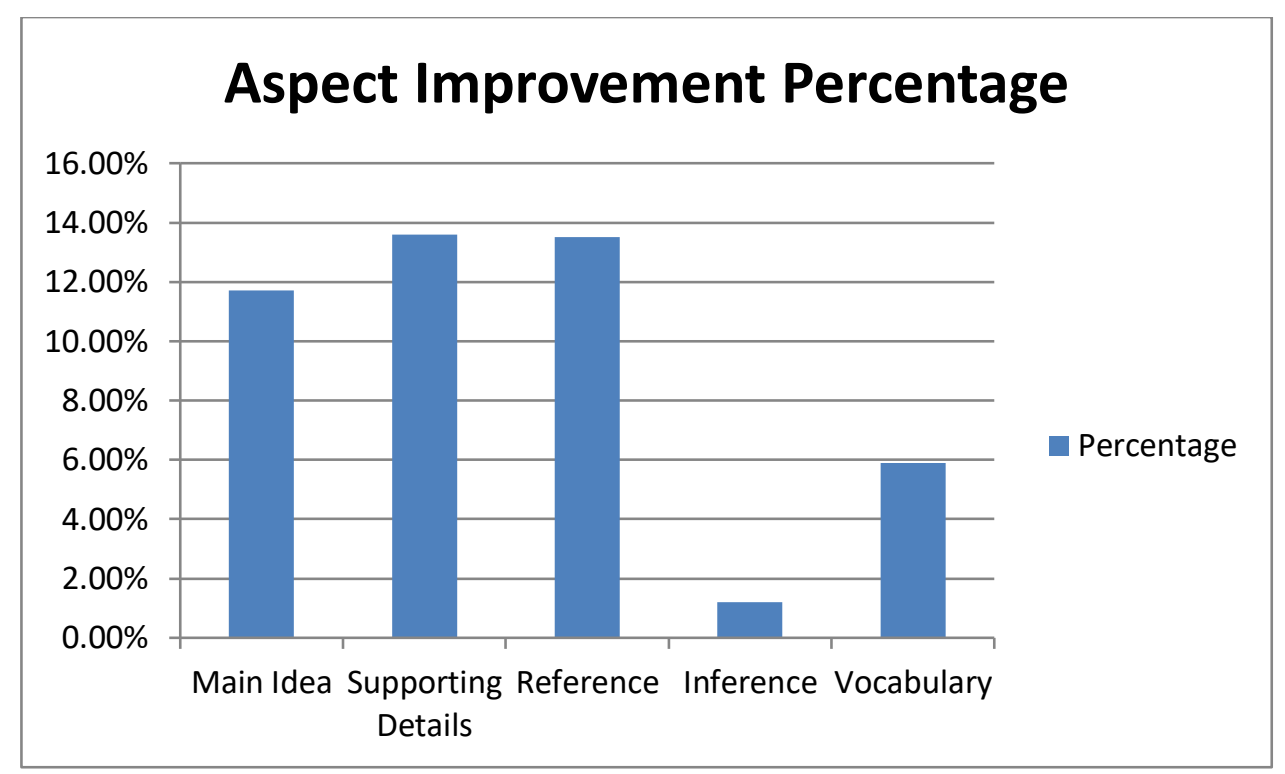

According to the figure above, there is improvement on students' reading achievement in some aspects of reading. The highest gain percentage is the aspect of supporting details (13.6\%). Supporting details is searching for the details relevant to the purpose in mind and trying to dismiss the irrelevant one (Nuttal, 1982). ReadTheory.org is an interactive website designed to serve as a computer-based supplemental reading program for students in grades 1 through 12 at ESL. The website provides a wide variety of reading exercises.

ReadTheory support the online reading habit among students. This finding supports the previous research that there was a correlation between students' online reading habit and their reading achievement (Yuliani, 2017). Students online reading habit as what happened in ReadTheory stimulates the students for getting higher score in answering post test. This is proven as the result of post test mean reached 62,59 from 53,40.

Table 3. Computation Paired Sample T-Test SPSS 20 Version

Paired Samples Statistics

\begin{tabular}{|lllllc|}
\hline & & Mean & N & Std. Deviation & $\begin{array}{c}\text { Std. Error } \\
\text { Mean }\end{array}$ \\
\hline \multirow{2}{*}{ Pair 1 } & PRE-TEST & 53.4091 & 22 & 10.84813 & 2.31283 \\
& POST-TEST & 62.5909 & 22 & 12.70043 & 2.70774 \\
\hline
\end{tabular}

Table 3 presents the mean scores of 22 students' reading achievement in both pre-test and post-test. It is shown that pre-test mean score is 53,40 while the post-test mean score is 62,59 . It means that there is improvement on students' reading achievement after the implementation of ReadTheory.

\section{Discussion}

The research finding indicates that the implementation of ReadTheory had led to significant improvement of students' reading achievement. The students' mean score in the pre-test was 53,40. In the post-test, students got 62,59 on their reading achievement. Then, it was found out that the significance level of students' improvement was 0,000. Therefore, it indicates that the implementation of ReadTheory as platform can significantly improve students' reading 
achievement. In the previous studies conducted by Romeo (2016), it was found out that the implementation of ReadTheory to the significant improvement on students reading performance in level of ESL. Additionally, the improvement was shown in some aspects of reading which were supporting details, reference and main idea.

There are five aspects of reading which are main idea, supporting details, reference, inference and vocabulary. The aspect significantly improved after teaching reading using ReadTheory is supporting details. Supporting details aim to extract specific information without reading through the whole text. From the result, it was found out that supporting details got the highest improvement compared to the other aspects. The gain percentage of supporting details was $13.6 \%$. The researcher then tried to analyze on why supporting details became the most improved aspect compared to the others.

Example of representative design supporting details:

\section{Independence Day Celebrate Peacefully Nationwide}

1,000 flags, one love. a young boy and girl banded together to secure a flagpole to the ground in mt. Merapi valley in yogyakarta on Sunday. The pole was one of 1,000 flags erected in the valley during a flag-raising ceremony entitled, "Seribu Bendera Satu Cinta" (a thousands flag, one love).

In medan, North Sumatra; the residents of Aurvillage held their flags-raising ceremony. The local governments paid attention to Usmarlin, a participant who said that the condition of the river had become a matter of great concern because of pollution from both factories and domestic waste.

Meanwhile, 2,343 prisoners in South Sulawesi received sentence reductions due to the independence day celebration, 92 of whom were released from prisoners.

The Jakarta Post, August 182014.

Question: Who enjoyed freedom in this independence day celebration?

(A) a young boy and girl

(B) Aurvillage residents

(C) the local governments

(D) the 2,343 prisoners

(E) the 92 prisoners

The typical of supporting details questions employed the question of 5W (what, when, why, who, where) questions. On the above, the question from national examination reading test used "who". The question ask "Who enjoyed freedom in this independence day celebration". As what being said, the aspect aims to extract specific information without reading through the whole text. The student did not need to read the whole text to find who enjoyed the independence day celebration. As the result, the students could easily answer the independence day celebration from the keywords they were asked for. This includes searching for the details relevant to the purpose in mind and trying to dismiss the irrelevant one (Nuttal, 1982). In short, the students of SMAN 11 Bandar Lampung are able to discriminate the relevant and irrelevant ones.

In the previous studies conducted reading online using ReadTheory, the improvement in aspects of reading such as main idea, supporting details, reference, inference and vocabulary have not 
investigated yet. However, Romeo (2016) found out that there is impact on student grades in the students in United States generally. In this research, the grades of students and the aspects of reading after using the website significantly increased. Thus, this research supports the previous finding and addresses more the aspects.

When reading habit become cultures, this website shifts the conventional reading cultures to be integrated by technology. Online reading resources are helpful to make students get ready to work the task, to get much information, and to improve learners' knowledge in reading (Satriani, 2019). The students took the ReadTheory worksheet regularly. The worksheet in ReadTheory targets students critical thinking as what 2013 curriculum expected (Kemdikbud, 2014). Online reading strategy gave a positive impact on students' pattern in English reading achievement. Therefore, this is in line with the previous study that online reading is an appropriate media to support English reading (Khusniyah, 2019).

The students motivation in doing exercises also has played a big role in reading achievement. The three aspects of reading motivation most relevant to the instruction of reading worksheet in ReadTheory: (a) improving reading self-efficacy; (b) making internal and controllable outcome attributions for successes and failures associated with reading; and (c) establishing personally relevant value in becoming a better reader (Quirk, 2010). The self-efficacy makes student finishing the task effectively in time. The outcome attributions associated with reading becomes a reflection since the result was being published in the website after completing the tasks. The establishment of personal relevant value in becoming better reader was stimulated by the gamified content to become a good achiever in finishing the task perfectly. So, this website has contributions for students.

\section{CONCLUSION AND SUGGESTIONS}

\section{Conclusion}

ReadTheory contains reflective exercises which is aimed at directing students to understand the meaning and intention of reading a specific piece of written content. Their knowledge of the intention of reading will allow them to decide the right skill(s) to use in later reading activities. The achievement of finding specific information of the text also happens in finding supporting details, reference and main idea. Those achievements are improved by reflective exercises in ReadTheory.

\section{Suggestion}

By considering the scope of this research, researchers who are interested in the same field are suggested to conduct a study on the use of ReadTheory the other language skills since this study only focused on the reading skill. On the other hand, ReadTheory gives worksheet in writing skills too for each reading exercise at the end. Researcher may also investigate the possibilities of reading aspects that might be least facilitated and identify the factors that possibly hinder them for this research focused more on the aspect of reading improved the most. Furthermore, the other researcher may conduct a research on the students' perception and the students' progress about the website. In brief, the conclusions of this research and the suggestions for English teachers who are interested to implement ReadTheory as website in media of teaching English who want to conduct any relevant researches have been explained. 


\section{REFERENCE}

Ayu. Mutiara. (2020). Online learning: Leading e-Learning at higher education. The Journal of English Literacy Education

Chastain, K. (1988). Developing second language skills: Theory and practice (3rd ed.). Florida: Harcourt Brace Jovanovich

Common Core State Standards for English Language Arts \& Literacy in History/Social Studies, Science, and Technical Subjects. (2010). Common core state standards initiative. Retrieved from http://www.corestandards.org/ELA-Literacy/

Fernando, W. (2018). Show me your true colours: Scaffolding formative academic literacy assessment through an online learning platform. Assessing Writing, (36), 63-76. doi: https://doi.org/10.1016/j.asw.2018.03.005

Haron, Nadia, N., Zaid, Hanafi, Y. \& Ibrahim, Aireen, N. (2015). E-Learning as a platform to learn English among ESL learners: benefits and barriers

Harmer, J. (2001). The practice of English language teaching. Longman

Khusniyah, N. L. (2019). Implementation online reading strategy on English reading achievement skills. ELITE Journal, 1 (1), 87-94

Lembaga Tes Masuk Perguruan Tinggi. (2020). FAQ tentang UTBK-SBMPTN. Retrieved from https://ltmpt.ac.id/?mid=12

Nuttal, C. (1982). Practical language teaching. Teaching reading skills in a foreign. language. Heinemann Educational Books

Quirk-Bolt.N, Metcalfe.N. (2010). 'Collaborative on-line learning in schools; teacher perceptions of purpose and effectiveness'. Technology, Pedagogy and Education

Romeo, G. (2016). ReadTheory.org data collection study 2.0: A preliminary study concerning the effectiveness of an online reading achievement and writing program . University of North Carolina at Chapel Hill

Satriani, E. (2019). Online reading resources among EFL (English Foreign Language) students: Do they promote reading habit? Universitas Islam Riau

Setiyadi, Ag. B. (2006). Metode penelitian untuk pengajaran bahasa asing: Pendekatan Kuantitatif dan Kualitatif. Yogyakarta: Graha Ilmu

Yuliani, S. (2017). The influence of online reading habit on reading achievement of the eleventh grade students of Senior High School Muhammadiyah 1 of Palembang. English Community Journal 